Abstracta Iranicacta Iranica

Revue bibliographique pour le domaine irano-aryen

Volume 28 | 2007

Comptes rendus des publications de 2005

"A note on a unique Islamic golden figurine ». Iran, XL, 2002, pp. 173-180

\title{
Youssef Ragheb
}

\section{(2) OpenEdition}

1 Journals

Édition électronique

URL : http://journals.openedition.org/abstractairanica/11612

DOI : 10.4000/abstractairanica. 11612

ISSN : 1961-960X

\section{Éditeur :}

CNRS (UMR 7528 Mondes iraniens et indiens), Éditions de l'IFRI

\section{Édition imprimée}

Date de publication : 15 mai 2007

ISSN : 0240-8910

\section{Référence électronique}

Youssef Ragheb, « «A note on a unique Islamic golden figurine ». Iran, XL, 2002, pp. 173-180», Abstracta Iranica [En ligne], Volume 28 | 2007, document 233, mis en ligne le 18 septembre 2007, consulté le 25 septembre 2020. URL : http://journals.openedition.org/abstractairanica/11612 ; DOI : https://doi.org/10.4000/abstractairanica.11612

Ce document a été généré automatiquement le 25 septembre 2020.

Tous droits réservés 


\title{
«A note on a unique Islamic golden figurine ». Iran, XL, 2002, pp. $173-180$
}

\section{Youssef Ragheb}

1 Bref article d'un grand intérêt consacré à une figurine de taille réduite $(7,5 \mathrm{~cm}$ de long sur 2 de large et 0,7 d'épaisseur) représentant un homme barbu et debout. A.S. y décrit minutieusement le décor qu'il compare à d'autres objets et suggère même, d'après les sources narratives, le nom que l'on donnait à cette technique particulière d'orfèvrerie. La date

(XI ${ }^{\mathrm{e}}$-XII ${ }^{\mathrm{e}}$ siècles) et la provenance (Asie centrale ou Iran) de cette pièce apparemment unique semblent possibles et même probables. On regrette toutefois que son lieu de découverte et sa destination restent inconnus.

\section{INDEX}

Thèmes : 5.1. Monde iranophone

\author{
AUTEURS \\ YOUSSEF RAGHEB \\ CNRS - Paris
}

